\title{
In patients with severe asthma with eosinophilia in reslizumab clinical trials, high peripheral blood eosinophil levels are associated with low $\mathrm{FEV}_{1}$ reversibility
}

\author{
J. Christian Virchow ${ }^{1 *}$, Lisa Hickey², Evelyn Du³ and Margaret Garin ${ }^{3}$
}

\begin{abstract}
Background: A post hoc analysis of two randomized, placebo-controlled, Phase 3 trials of intravenous reslizumab, an anti-interleukin-5 (IL-5) biologic for severe eosinophilic asthma.

Methods: Relationships between baseline blood eosinophil levels (EOS), forced expiratory volume in $1 \mathrm{~s}\left(\mathrm{FEV}_{1}\right)$ reversibility to $\beta_{2}$-agonists and treatment outcomes were assessed.

Results: Mean baseline $\mathrm{FEV}_{1}$ reversibility was numerically lower among patients with high ( $\geq 400 \mathrm{cells} / \mu \mathrm{L}$ ) versus low baseline EOS. Reslizumab produced clinically significant improvement in $\mathrm{FEV}_{1}$, exacerbation rates and patientreported outcomes after 52 weeks, including in patients with high EOS and low FEV 1 reversibility $(\leq 14 \%)$ to $\beta_{2^{-}}$ agonists at baseline.
\end{abstract}

Conclusions: Clinical trial eligibility criteria stipulating minimum $\mathrm{FEV}_{1}$ reversibility to $\beta_{2}$-agonists of $\geq 12 \%$ might exclude patients who would benefit from treatment with anti-IL-5 biologics.

Keywords: Asthma, Clinical trials, Eosinophils, Lung function

\section{Introduction}

Severe non-allergic, adult-onset or intrinsic asthma is frequently associated with pronounced eosinophilia [14]. Interleukin-5 (IL-5) is a potent activator of eosinophils and enhances their viability [5]. IL-5 activity has been demonstrated to inversely correlate with pulmonary function in patients with asthma [4], and anti-IL-5 treatment has been shown to improve asthma control in patients with severe asthma and eosinophilia [6].

Reslizumab is an IgG4-kappa humanized monoclonal antibody targeting IL-5 [7]. In Phase 3 clinical trials intravenous (IV) reslizumab dosed at $3 \mathrm{mg} / \mathrm{kg}$ once every

*Correspondence: j.c.virchow@med.uni-rostock.de

${ }^{1}$ Departments of Pneumology/Intensive Care Medicine, University Medical Center, University of Rostock, Rostock, Germany

Full list of author information is available at the end of the article
4 weeks (q4w) was associated with a significant reduction in the risk of clinical asthma exacerbations (CAEs) and improved asthma control, lung function, and quality of life in patients with inadequately controlled asthma with blood eosinophil levels (EOS) $\geq 400$ cells $/ \mu \mathrm{L}$ and a history of CAEs [8]. Reslizumab has been indicated as add-on maintenance treatment for adult patients with severe eosinophilic asthma [9].

Among the entry criteria for these trials, patients had to have EOS $\geq 400$ cells $/ \mu \mathrm{L}$ at screening. In addition, based on traditional concepts to substantiate the presumed diagnosis of asthma, all patients had to demonstrate a reversibility of their forced expiratory volume in $1 \mathrm{~s}\left(\mathrm{FEV}_{1}\right)$ in response to the inhalation of a $\beta_{2}$ agonist (albuterol $200 \mu \mathrm{g}$ ) of $\geq 12 \%$. A recent longitudinal cohort study in young adults, with and without asthma, 
has shown that elevated EOS are associated with airflow obstruction [10].

We therefore hypothesized that any substantial increase in $\mathrm{FEV}_{1}$ following the administration of a $\beta_{2}$-agonist might reflect asthma dominated by smooth muscle contraction rather than eosinophilic inflammation. On the other hand, a poor response to $\beta_{2}-$ agonists in patients with severe asthma and eosinophilia might predict a better response to anti-IL-5 therapy. To substantiate this we performed a post hoc analysis of data from two Phase 3 trials of IV reslizumab (NCT01287039 and NCT01285323) [8] to assess the relationship between EOS, reversibility of airway obstruction and treatment response to reslizumab therapy in a well-characterized population of patients with inadequately controlled moderate-to-severe asthma with EOS $\geq 400$ cells $/ \mu \mathrm{L}$.

\section{Methods}

\section{Study design and patients}

The two duplicate trials enrolled patients aged 12-75 years with inadequately controlled asthma (Asthma Control Questionnaire-7 [ACQ-7] score $\geq 1.5$ ) on medium-to-high doses of inhaled corticosteroids (ICS), and who had screening EOS $\geq 400$ cells $/ \mu \mathrm{L}, \geq 1$ $\mathrm{CAE}$ in the previous year, and $\mathrm{FEV}_{1}$ reversibility of $\geq 12 \%$ with albuterol [8]. The selection criteria for $\mathrm{FEV}_{1}$ reversibility were chosen based on National Asthma Education and Prevention Program guidelines available at the time of study design [11].

Both trials were conducted in accordance with Good Clinical Practice guidelines, the Declaration of Helsinki, and local regulatory requirements. All patients provided written informed consent, and the relevant health authorities and local ethics committees or institutional review boards approved the study protocols.

Following a 2-4-week screening period, patients were randomized (1:1) to receive IV reslizumab $(3.0 \mathrm{mg} / \mathrm{kg})$ or matching placebo $\mathrm{q} 4 \mathrm{w}$ for 52 weeks. Patients continued their usual asthma treatment during the screening, run-in and treatment periods. Pre-bronchodilator spirometry, Asthma Symptom Utility Index (ASUI), and ACQ-7 were assessed $\mathrm{q} 4 \mathrm{w}$ at the scheduled clinic visits, from day of randomization to the end of treatment. Possible cases of CAEs were assessed by questioning of the patient at every scheduled monthly visit. Asthma Quality of Life Questionnaire (AQLQ) score was assessed at baseline and weeks 16, 32, and 52 .

\section{Outcome measures}

$\mathrm{FEV}_{1}$ reversibility at baseline (during screening) was assessed according to EOS category at baseline (day of first dose). Categories for baseline $\mathrm{FEV}_{1}$ reversibility were arbitrarily set at $<14 \%, 14$ to $<16 \%, 16$ to $<20 \%$ and $\geq 20 \%$, with baseline EOS categories set arbitrarily at $<150$ cells $/ \mu \mathrm{L}, 150$ to $<400$ cells $/ \mu \mathrm{L}, 400$ to $<700$ cells/ $\mu \mathrm{L}$ and $\geq 700$ cells $/ \mu \mathrm{L}$. Given that blood eosinophil counts are known to be variable over time, assessment of blood eosinophil count at baseline allowed for selection of patients with persistently elevated blood eosinophils $\geq 400$ cells $/ \mu \mathrm{L}$ at two timepoints (screening and baseline).

The effect of reslizumab versus placebo on asthma clinical outcomes was also assessed in the subgroup with baseline low $\mathrm{FEV}_{1}$ reversibility (12-14\%) and pooled high EOS $(\geq 400$ cells $/ \mu \mathrm{L})$. Assessment of lung function comprised $\mathrm{FEV}_{1}, \mathrm{FEV}_{1} \%$ predicted, forced vital capacity (FVC) and forced expiratory flow at $25-75 \%$ of pulmonary volume $\left(\mathrm{FEF}_{25-75 \%}\right)$, and other asthma clinical outcomes assessed were CAEs, ACQ-7, AQLQ and ASUI.

\section{Statistical analysis}

An analysis of covariance was used to model change from baseline at Week 52 in lung function and patientreported outcomes (ACQ-7, AQLQ and ASUI) with fixed factors for treatment arm, sex, oral corticosteroid use at baseline (Yes or No), region (USA or Other), and a continuous covariate for height.

CAEs counted are those which occurred between the completion of the first dose of study drug and 2 weeks after the end of treatment/early withdrawal visit. CAE rates, CAE rate ratio, and confidence intervals $(\mathrm{CIs})$ and $p$ values are based on a negative binomial regression model adjusted for baseline usage of oral corticosteroid (Yes or No) and region (USA or other).

All analyses were conducted using SAS version 9.4 (SAS Institute Inc., Cary, NC, USA).

\section{Results}

A total of 953 patients were randomized in the two duplicate Phase 3 studies (reslizumab: $n=477$; placebo: $n=476$ ). Patient demographics and clinical characteristics at baseline were similar between reslizumab and placebo groups (Table 1).

\section{Baseline eosinophil categories and $\mathrm{FEV}_{1}$ reversibility}

During the screening period, all patients were required to have EOS $\geq 400$ cells $/ \mu \mathrm{L}$. However, on the day of the first reslizumab dose, 65 patients had EOS $<150$ cells $/ \mu \mathrm{L}$, 179 patients had EOS 150 to $<400$ cells $/ \mu \mathrm{L}, 365$ patients had EOS 400 to $<700$ cells $/ \mu \mathrm{L}$, and 344 patients had $\mathrm{EOS} \geq 700$ cells $/ \mu \mathrm{L}$. At baseline, 149 patients had an FEV reversibility of $<14 \%$ (between 12 and 14\%), 104 had reversibility between $14 \%$ and $<16 \%, 172$ had reversibility of $16-20 \%$, and 528 had reversibility of $\geq 20 \%$. Across EOS subgroups, baseline mean $\mathrm{FEV}_{1}$ was numerically lowest in the $E O S \geq 700$ cells $/ \mu \mathrm{L}$ subgroup for both 
Table 1 Patient characteristics during the baseline period

\begin{tabular}{|c|c|c|}
\hline Characteristic baseline subgroup & Placebo $(\mathrm{N}=476)$ & Reslizumab $(\mathrm{N}=477)$ \\
\hline Mean age (SD), years & $47.1(14.3)$ & $46.5(13.8)$ \\
\hline Females, n (\%) & $311(65)$ & $286(60)$ \\
\hline Mean body mass index (SD), $\mathrm{kg} / \mathrm{m}^{2}$ & $27.5(5.7)$ & $27.4(5.8)$ \\
\hline Oral corticosteroid use, n (\%) & $73(15)$ & $73(15)$ \\
\hline LABA use, $n(\%)$ & $383(80)$ & $397(83)$ \\
\hline High-dose ICS a use, n (\%) & $208(44)$ & $203(43)$ \\
\hline Mean FEV 1 (SD), mL & $1965(734)$ & $2008(763)$ \\
\hline $\mathrm{EOS}<150$ cells $/ \mu \mathrm{L}$ & $1947(643)$ & $2317(834)$ \\
\hline EOS 150 to $<400$ cells $/ \mu \mathrm{L}$ & $2101(759)$ & $2032(734)$ \\
\hline EOS 400 to $<700$ cells $/ \mu \mathrm{L}$ & $1997(795)$ & $2091(785)$ \\
\hline $\mathrm{EOS} \geq 700$ cells $/ \mu \mathrm{L}$ & $1860(655)$ & $1846(710)$ \\
\hline FEV , reversibility $<14 \%$ & $2258(735)$ & $1975(754)$ \\
\hline $\mathrm{FEV}_{1}$ reversibility 14 to $<16 \%$ & $2187(666)$ & $2180(659)$ \\
\hline $\mathrm{FEV}_{1}$ reversibility 16 to $20 \%$ & $1944(838)$ & $2045(821)$ \\
\hline FEV, reversibility $\geq 20 \%$ & $1841(678)$ & $1979(763)$ \\
\hline Mean FEV 1 predicted (SD), \% & $66.5(19.4)$ & $66.9(20.0)$ \\
\hline Mean FEV ${ }_{1}$ reversibility (SD), \% & $27.5(21.1)$ & $27.0(15.8)$ \\
\hline Mean FVC (SD), mL & $3008(1030)$ & $3070(1010)$ \\
\hline Mean blood EOS (SD), cells/ $\mu \mathrm{L}$ & $655(637)$ & $654(621)$ \\
\hline Mean age of asthma onset (SD), years & $27.8(17.9)$ & $27.3(18.4)$ \\
\hline
\end{tabular}

a High-dose ICS use was defined as when one of the following was true at enrolment: fluticasone $>500 \mu \mathrm{g} /$ day, mometasone $>440 \mu \mathrm{g} / \mathrm{day}$, budesonide $>800 \mu \mathrm{g} / \mathrm{day}$, ciclesonide $>320 \mu \mathrm{g} /$ day, beclomethasone $>400 \mu \mathrm{g} /$ day or triamcinolone $>2000 \mu \mathrm{g} /$ day

EOS eosinophil, FEV forced expiratory volume in $1 \mathrm{~s}$, FVC forced vital capacity, ICS inhaled corticosteroid, LABA long-acting beta agonist, SD standard deviation

reslizumab and placebo (Table 1). There was no clear relationship between baseline mean $\mathrm{FEV}_{1}$ and $\mathrm{FEV}_{1}$ reversibility subgroup (Table 1 ). Baseline mean $\mathrm{FEV}_{1}$ was generally comparable between reslizumab and placebo treatment arms within patient subgroups (Table 1).

\section{Baseline $\mathrm{FEV}_{\mathbf{1}}$ reversibility according to eosinophil group}

Those patients who had low baseline EOS $(<150$ cells/ $\mu \mathrm{L}$ or 150 to $<400$ cells $/ \mu \mathrm{L}$ ) had a higher mean $\mathrm{FEV}_{1}$ reversibility and a higher proportion of patients who were highly reversible to inhaled $\beta_{2}$-agonists $(\geq 20 \%$ reversibility, $60 \%$ and $62.6 \%$ of the subgroup populations) compared with patients with higher EOS (Fig. 1). The proportion of patients who responded relatively poorly to $\beta_{2}$-agonists $(<14 \%$ improvement $)$ was largest in the $E O S \geq 700$ cells $/ \mu \mathrm{L}$ group (17.4\%) compared with other EOS groups, and this high EOS group had the numerically lowest mean reversibility (Fig. 2).

\section{Reslizumab treatment effect on lung function measures}

Figure 3 shows the observed treatment effects for reslizumab on $\mathrm{FEV}_{1}$ versus placebo at 52 weeks in the group comprising patients with high EOS and the lowest $\mathrm{FEV}_{1}$ reversibility $(\mathrm{EOS} \geq 400$ cells $/ \mu \mathrm{L},<14 \%$ reversibility) compared with the remaining overall population excluding those with $E O S \geq 400$ cells $/ \mu \mathrm{L}$ and $<14 \%$ reversibility. Both groups experienced a clinically significant improvement in $\mathrm{FEV}_{1}$ at 52 weeks with reslizumab versus placebo (mean: $+174 \mathrm{~mL}[95 \%$ CI 1-348] and $+139 \mathrm{~mL}$ [95\% CI 76-202], respectively). Interestingly, despite the relatively poor response to $\beta_{2}$ agonists, in the EOS high $/ \beta_{2}$-agonist reversibility low group there was a marked improvement compared with placebo, with a numerically greater treatment effect compared with the remaining population. The absolute increase in $\mathrm{FEV}_{1}$ in $\mathrm{mL}$ from baseline after 52 weeks in the high EOS/low $\beta_{2}$-agonist reversibility group was numerically higher than the change from baseline in the remaining patient population with both reslizumab treatment (mean: $+439 \mathrm{~mL}$ [standard error [SE] 105] and $+270 \mathrm{~mL}$ [SE 36]) and placebo (mean: $+265 \mathrm{~mL}$ [SE 98] and $+130 \mathrm{~mL}$ [SE 37]). However, numerical differences in treatment effect for $\mathrm{FEV}_{1}$ between the EOS high $/ \beta_{2}$ agonist reversibility low group and the remaining population did not reach statistical significance. Baseline values and treatment effects in these two groups on $\mathrm{FEV}_{1}, \mathrm{FVC}$ and $\mathrm{FEF}_{25-75 \%}$ are shown in Table 2. 


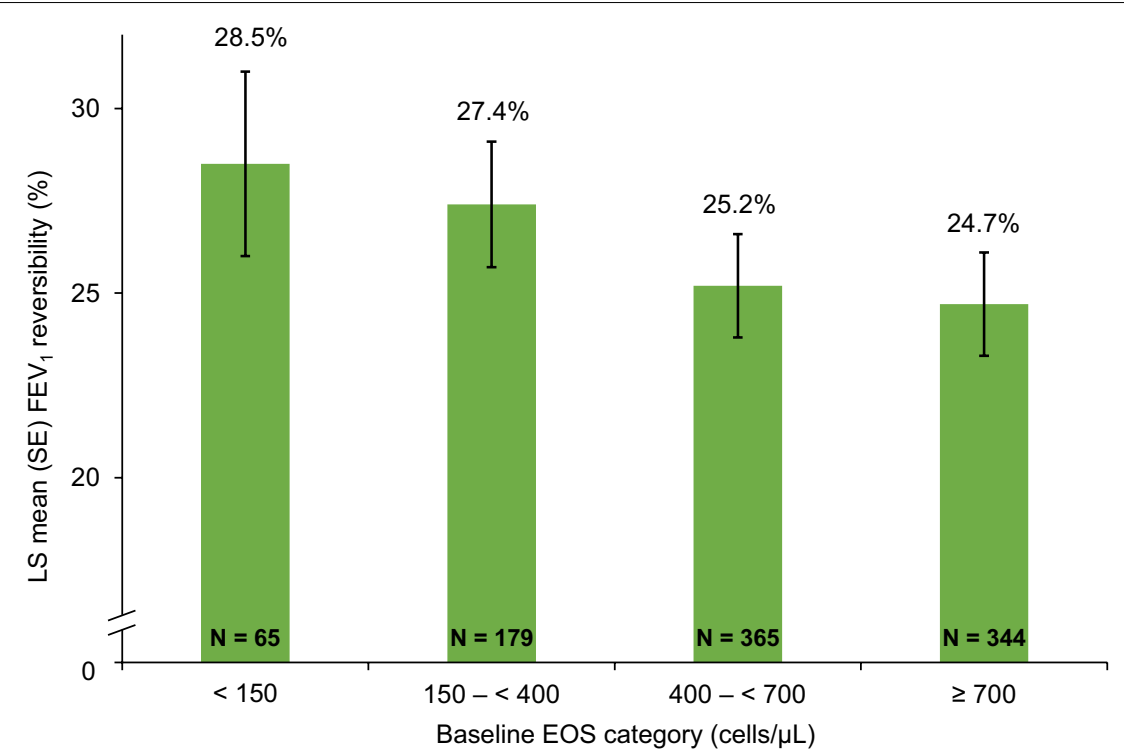

Fig. 1 Mean baseline FEV reversibility according to baseline blood eosinophil category. EOS blood eosinophil level; FEV forced expiratory volume in $1 \mathrm{~s}$; LS least-squares; SE standard error

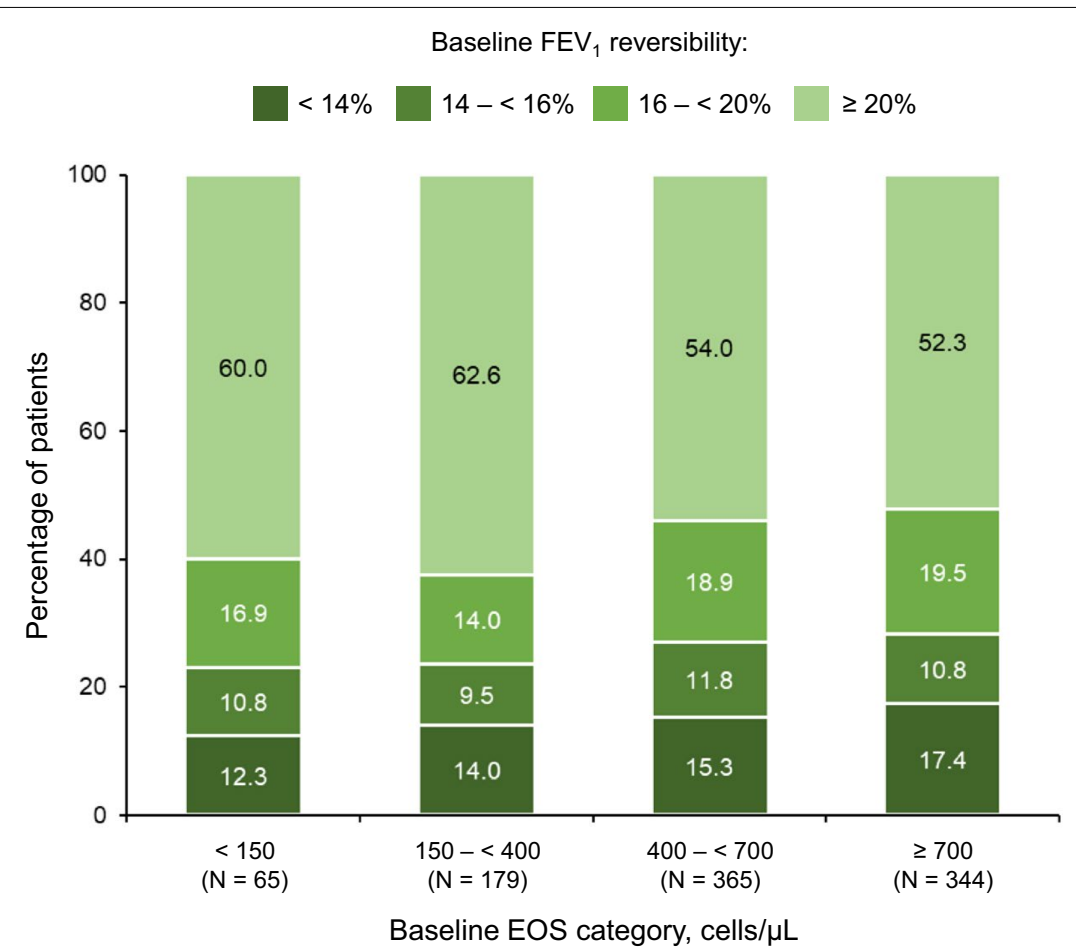

Fig. 2 Proportions of patients in each category of baseline FEV 1 reversibility according to baseline EOS. EOS blood eosinophil level; FEV forced expiratory volume in $1 \mathrm{~s}$ 


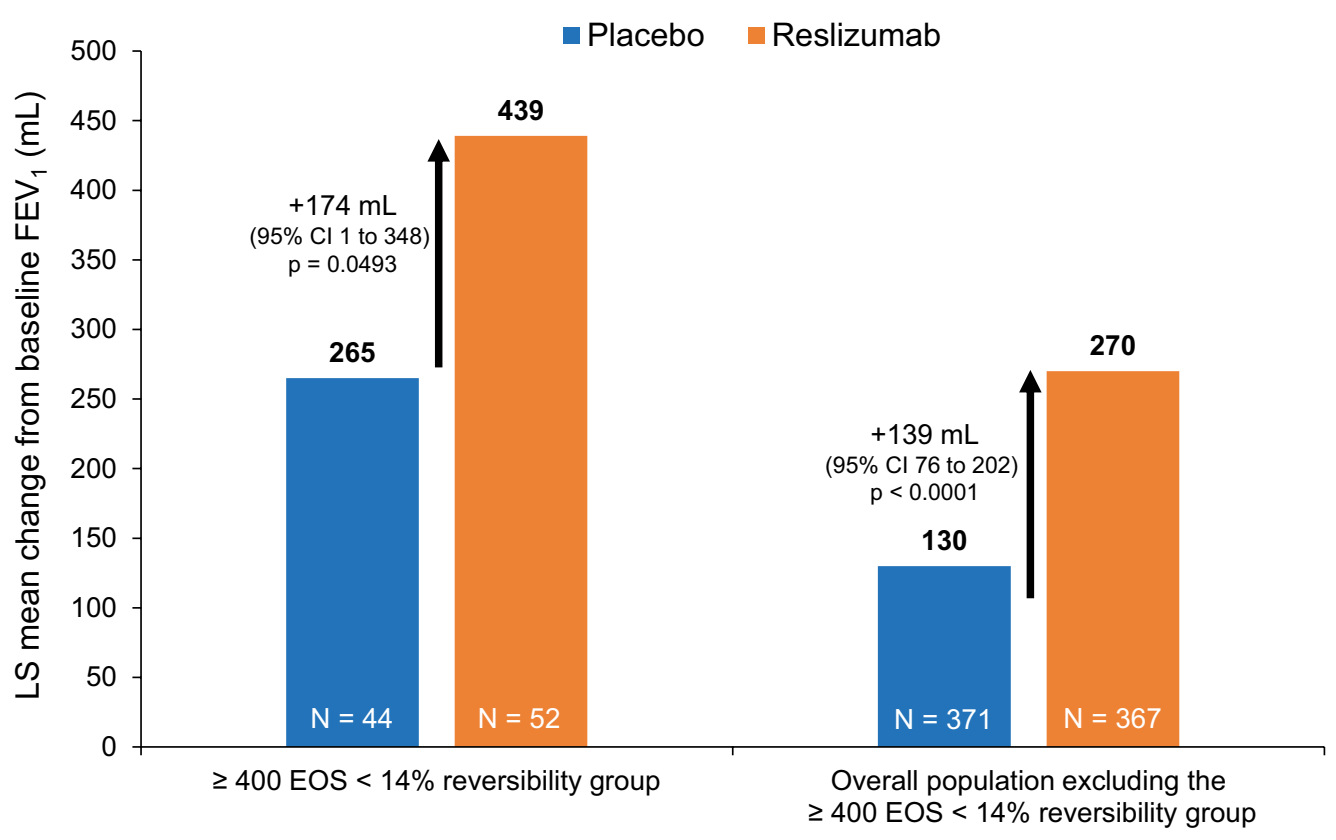

\begin{tabular}{|l|c|c|c|c|}
\hline & \multicolumn{2}{|c|}{ (400 EOS $<\mathbf{1 4 \%}$ reversibility group } & $\begin{array}{c}\text { Overall population excluding } \\
\mathbf{4 0 0} \text { EOS < 14\% reversibility group }\end{array}$ \\
\hline & Placebo & Reslizumab & Placebo & Reslizumab \\
\hline \multicolumn{5}{|c|}{$\mathbf{N}$} \\
\hline Baseline & 52 & 64 & 424 & 413 \\
\hline $\mathbf{5 2}$ weeks & 42 & 52 & 358 & 365 \\
\hline \multicolumn{5}{|c|}{ Change from baseline FEV $\mathbf{1}(\mathbf{m L})$} \\
\hline Mean & 46 & 194 & 106 & 253 \\
\hline Median & -60 & 145 & 60 & 170 \\
\hline Lower, Upper Quartile & $-190,230$ & $-65,425$ & $-140,310$ & $-50,430$ \\
\hline Min, Max & $-1370,1310$ & $-390,1020$ & $-1440,1890$ & $-880,2480$ \\
\hline
\end{tabular}

Fig. 3 Change from baseline FEV 1 at 52 weeks among patients with high EOS and low reversibility, compared with the overall population excluding these patients. Cl confidence interval; EOS blood eosinophil level; FEV forced expiratory volume in $1 \mathrm{~s}$; IQR interquartile range; LS least-squares

\section{Reslizumab treatment effect on other asthma clinical measures}

At 52 weeks, mean annualized exacerbation rate was lower with reslizumab versus placebo in the high EOS/low $\beta_{2}$-agonist reversibility group (0.63 vs 1.06 , respectively; rate ratio 0.60 [95\% CI $0.33,1.09$ ]; $p=0.0937)$ and in the remaining overall population excluding those with $\mathrm{EOS} \geq 400$ cells $/ \mu \mathrm{L}$ and $<14 \%$ reversibility $(0.59$ vs 1.19 , respectively; rate ratio 0.45 [95\% CI 0.35, 0.57]; $p<0.0001$ ) (Table 3). The CAE rate ratio for reslizumab versus placebo was numerically lower in the remaining overall population excluding those with EOS $\geq 400$ cells $/ \mu \mathrm{L}$ and $<14 \%$ reversibility compared to the high EOS/low $\beta_{2}$-agonist reversibility group, although numerical differences did not reach statistical significance between groups.

Baseline values and treatment effects on ACQ, AQLQ and ASUI in the high EOS/low $\beta_{2}$-agonist reversibility group and the remaining overall population excluding those with EOS $\geq 400$ cells $/ \mu \mathrm{L}$ and $<14 \%$ reversibility are shown in Table 3. Similar to the lung function findings, we observed a numerically greater treatment effect for reslizumab versus placebo across the asthma clinical outcomes in the high EOS/low $\beta_{2}$-agonist reversibility group than in the remaining overall population excluding those with $\mathrm{EOS} \geq 400$ cells $/ \mu \mathrm{L}$ and $<14 \%$ reversibility, with no statistically significant differences between groups.

\section{Discussion}

Eosinophilia is an important but often variable feature of bronchial asthma, which is highly responsive to corticosteroids and anti-IL-5 therapy. Based on our observation we can postulate that patients with the highest EOS were more likely to have a relatively poor reversibility to $\beta_{2}$-agonists, but were as likely to have 
Table 2 Change from baseline in lung function parameters after 52 weeks

\begin{tabular}{|c|c|c|c|c|c|c|}
\hline & \multicolumn{2}{|l|}{ Placebo } & \multicolumn{2}{|c|}{ Reslizumab } & \multirow{2}{*}{$\begin{array}{l}\text { 52-week treatment difference } \\
\text { (reslizumab vs placebo) }(95 \% \mathrm{Cl})\end{array}$} & \multirow[t]{2}{*}{$p$ value } \\
\hline & Baseline & Change at 52 weeks & Baseline & Change at 52 weeks & & \\
\hline \multicolumn{7}{|c|}{$\geq 400 \mathrm{EOS}<14 \%$ reversibility group } \\
\hline $\mathrm{N}$ & 52 & 42 & 64 & 52 & & \\
\hline $\mathrm{FEV}_{1}, \mathrm{~mL}$ & $2339(107)$ & $265(98)$ & $1945(92)$ & $439(105)$ & 174 (1 to 348$)$ & 0.0493 \\
\hline $\mathrm{FEV}_{1} \%$ predicted & $73.3(2.6)$ & $6.7(3.2)$ & $67.4(2.2)$ & $13.8(3.4)$ & $7.1(1.4$ to 12.7$)$ & 0.0144 \\
\hline $\mathrm{FVC}, \mathrm{mL}$ & $3.5(0.14)$ & $271(121)$ & $2.9(0.13)$ & $419(129)$ & $148(-65$ to 362$)$ & 0.1714 \\
\hline $\mathrm{FEF}_{25-75 \%}, \mathrm{~mL}^{\mathrm{a}}$ & $1.7(0.14)$ & $297(133)$ & $1.3(0.090)$ & $444(141)$ & $147(-88$ to 383$)$ & 0.2172 \\
\hline \multicolumn{7}{|c|}{ Overall population excluding the $\geq 400 \mathrm{EOS}<14 \%$ reversibility group } \\
\hline $\mathrm{N}$ & 424 & 358 & 413 & 365 & & \\
\hline $\mathrm{FEV}_{1}, \mathrm{~mL}$ & $1919(35)$ & $130(37)$ & $2018(38)$ & $270(36)$ & 139 (76 to 202) & $<0.0001$ \\
\hline $\mathrm{FEV}_{1} \%$ predicted & $65.7(0.94)$ & $4.7(1.2)$ & $66.8(1.0)$ & $9.1(1.2)$ & 4.4 (2.3 to 6.5$)$ & $<0.0001$ \\
\hline $\mathrm{FVC}, \mathrm{mL}$ & $2.9(0.049)$ & $157(46)$ & $3.1(0.049)$ & $288(45)$ & $131(52$ to 210$)$ & 0.0013 \\
\hline $\mathrm{FEF}_{25-75 \%}, \mathrm{~mL}^{\mathrm{b}}$ & $1.7(0.29)$ & $79(53)$ & $1.4(0.043)$ & $207(51)$ & 128 (39 to 217 ) & 0.0047 \\
\hline
\end{tabular}

Baseline data are mean (SE). All change from baseline data are LS mean (SE)

$\mathrm{Cl}$ confidence interval, EOS blood eosinophil level, $F E F_{25-75 \%}$ forced expiratory flow at $25-75 \%$ of pulmonary volume, $F E V$, forced expiratory volume in $1 \mathrm{~s}$, $F V C$ forced vital capacity, LS least square, SE standard error

a $\mathrm{FEF}_{25-75 \%}$ data unavailable for $\mathrm{n}=1$ (placebo), $\mathrm{n}=1$ (reslizumab) patients

b $\mathrm{FEF}_{25-75 \%}$ data unavailable for $\mathrm{n}=3$ (placebo), $\mathrm{n}=5$ (reslizumab) patients

a marked response to treatment with the anti-IL-5 antagonist reslizumab as the remaining population.

Unfortunately, due to standard asthma inclusion criteria for reversibility used in this study, no patients with $\mathrm{EOS} \geq 400$ cells $/ \mu \mathrm{L}$ and a $\beta_{2}$-agonist reversibility of $\leq 12 \%$ were studied. Based on our observed results it can be speculated, however, that these patients might have benefited from treatment with reslizumab as the lack of $\mathrm{FEV}_{1}$ increase following the administration of a $\beta_{2}$-agonist might reflect asthma dominated by eosinophilic inflammation. Therefore, this population should be specifically investigated in a future study. At present, our data suggest that high $\beta_{2}$-agonist reversibility might not be the best predictor of response to anti-IL-5 treatment while low $\beta_{2}$-reversibility (in the presence of a marked eosinophilia) might be indicative of eosinophil-dependent asthma. Future studies should therefore test if the combination of the two 'biomarkers', namely a low $\beta_{2}$-agonist reversibility together with a high peripheral blood eosinophilia, might be a better predictor of response to anti-IL-5 therapy than either parameter alone or other markers such as fractioned exhaled nitric oxide currently used to predict treatment responses in asthma. Finally, our observation suggests that in asthma low $\beta_{2}$-agonist reversibility in the presence of eosinophilia should not lead to the assumption of an irreversibility of airflow obstruction, but in contrast might be indicative of persistent eosinophilic inflammation rather than 'remodeling', which might predict a marked responsiveness to antiinflammatory treatment with corticosteroids and/or anti-IL-5 treatments.

In this study, we noted a large increase in $\mathrm{FEV}_{1}$ from baseline in the placebo groups, particularly in the EOS high $/ \beta_{2}$-agonist reversibility low group. The marked improvement in $\mathrm{FEV}_{1}$ after 52 weeks in the EOS high/ $\beta_{2}$-agonist reversibility low group receiving placebo may be due to a 'trial effect' including increased adherence to ICS, which might preferentially result in improvement in eosinophilic patients. However, the improvement on reslizumab was numerically better in this group than in the remaining patients, suggesting that a possibly good response in $\mathrm{FEV}_{1}$ to ICS does not seem to interfere with the actions of reslizumab on airflow obstruction in eosinophilic patients.

\section{Limitations of the study}

Our study is limited by the post hoc nature of our analysis and the relatively small number of patients in the subgroup of interest $(n=52$ in the group with the lowest reversibility to $\beta_{2}$-agonists treated with reslizumab). Furthermore, our hypothesis that the biomarker combination of high peripheral blood eosinophilia/low $\beta_{2}$-agonist reversibility might be an ideal predictor of response to reslizumab is limited by the inclusion criteria of $\mathrm{FEV}_{1}$ reversibility of $\geq 12 \%$ precluding assessment of patients with lower baseline reversibility values. 
Table 3 Clinical asthma endpoints

\begin{tabular}{|c|c|c|c|c|c|c|}
\hline & \multicolumn{2}{|l|}{ Placebo } & \multicolumn{2}{|l|}{ Reslizumab } & \multirow[b]{2}{*}{ Treatment effect } & \multirow[b]{2}{*}{$p$ value } \\
\hline & Baseline & 52 weeks & Baseline & 52 weeks & & \\
\hline \multicolumn{7}{|l|}{$\geq 400$ EOS $<14 \%$ reversibility group } \\
\hline & & & & & $\begin{array}{l}\text { RR (reslizumab vs placebo) (95\% } \\
\text { CI) }\end{array}$ & \\
\hline$\geq 1$ exacerbation, $n(\%)$ & NA & $28(53.8 \%)$ & NA & $26(40.6 \%)$ & & \\
\hline \multirow{2}{*}{$\begin{array}{l}\text { Adjusted exacerbation rate (over } \\
52 \text { weeks) }{ }^{a}(95 \% \mathrm{Cl})\end{array}$} & NA & $1.52(0.84,2.72)$ & NA & $0.91(0.48,1.72)$ & $0.600(0.330,1.090)$ & 0.0937 \\
\hline & & $\begin{array}{l}\text { Change } \\
\text { from baseline } \\
\text { at Week } 52\end{array}$ & & $\begin{array}{l}\text { Change } \\
\text { from baseline } \\
\text { at Week } 52\end{array}$ & $\begin{array}{l}\text { 52-week treatment difference } \\
\text { (reslizumab vs placebo) }(95 \% \\
\text { Cl) }\end{array}$ & \\
\hline N & 52 & 44 & 64 & 52 & & \\
\hline ACQ-7 score ${ }^{b}$ & $2.511(0.117)$ & $-0.781(0.158)$ & $2.464(0.111)$ & $-1.189(0.159)$ & $-0.408(-0.753,-0.064)$ & 0.0206 \\
\hline AQLQ score ${ }^{b}$ & $4.259(0.153)$ & $0.872(0.198)^{c}$ & $4.518(0.140)$ & $1.425(0.200)$ & $0.554(0.148,0.959)$ & 0.0079 \\
\hline ASUI score ${ }^{b}$ & $0.634(0.028)$ & $0.118(0.029)^{c}$ & $0.690(0.024)$ & $0.193(0.029)^{c}$ & $0.075(0.013,0.137)$ & 0.0174 \\
\hline
\end{tabular}

Overall population excluding the $\geq 400 \mathrm{EOS}<14 \%$ reversibility group

\begin{tabular}{|c|c|c|c|c|c|c|}
\hline$\geq 1$ exacerbation, $n(\%)$ & NA & $209(49.3 \%)$ & NA & 125 (30.3\%) & & \\
\hline Adjusted exacerbation rate over & NA & $1.80(1.37,2.36)$ & NA & $0.80(0.61,1.05)$ & $0.446(0.346,0.575)$ & $<0.0001$ \\
\hline & & $\begin{array}{l}\text { Change } \\
\text { from baseline } \\
\text { at Week } 52\end{array}$ & & $\begin{array}{l}\text { Change } \\
\text { from baseline } \\
\text { at Week } 52\end{array}$ & $\begin{array}{l}\text { 52-week treatment difference } \\
\text { (reslizumab vs placebo) (95\% } \\
\text { CI) }\end{array}$ & \\
\hline $\mathrm{N}$ & 424 & 371 & 413 & 367 & & \\
\hline ACQ-7 score ${ }^{b}$ & $2.708(0.041)$ & $-0.805(0.065)$ & $2.637(0.043)$ & $-1.141(0.064)$ & $-0.336(-0.470,-0.201)$ & $<0.0001$ \\
\hline AQLQ score ${ }^{b}$ & $4.182(0.053)$ & $0.874(0.077)^{d}$ & $4.297(0.053)$ & $1.171(0.076)^{c}$ & $0.297(0.150,0.445)$ & $<0.0001$ \\
\hline ASUI score ${ }^{b}$ & $0.630(0.010)$ & $0.145(0.012)^{e}$ & $0.641(0.010)$ & $0.198(0.012)^{f}$ & $0.053(0.028,0.078)$ & $<0.0001$ \\
\hline $\begin{array}{l}\text { ACQ Asthma Control Questionnaire, } A \\
\text { level, } L S \text { least square, } N A \text { not applicab }\end{array}$ & $\begin{array}{l}\text { Asthma Qual } \\
\text { standard err }\end{array}$ & y of Life Question & SUI Asthm & ptom Utility & I confidence interval, EOS blood ec & ophil \\
\hline $\begin{array}{l}\text { a Adjusted exacerbation rates and co } \\
\text { geographical region (US or other) }\end{array}$ & ence intervals & sed on Negative & nial regressic & nodel adjusted & seline use of oral corticosteroids (ye & no) and \\
\hline${ }^{b}$ Baseline data are mean (SE). All cha & from baseline & data are LS mean (S & & & & \\
\hline c Data unavailable for one patient & & & & & & \\
\hline${ }^{d}$ Data unavailable for three patients & & & & & & \\
\hline e Data unavailable for five patients & & & & & & \\
\hline${ }^{f}$ Data unavailable for four patients & & & & & & \\
\hline
\end{tabular}

\section{Conclusion}

Higher baseline EOS are associated with numerically lower $\mathrm{FEV}_{1}$ reversibility in patients with inadequately controlled asthma with eosinophilia. Reslizumab treatment resulted in clinically significant improvements in asthma clinical outcomes in patients with high EOS and low $\mathrm{FEV}_{1}$ reversibility at baseline. Therefore, reslizumab may preferentially reverse airway obstruction which appears 'fixed' to $\beta_{2}$ agonists (albuterol) due to action on IL-5 and airway eosinophils. The exclusion of patients with airflow obstruction poorly responsive to $\beta_{2}$-agonists from clinical trials of biologics for severe asthma may result in an under-representation of patients with enhanced inflammation with eosinophils who might in fact particularly benefit from this treatment.

\section{Abbreviations}

ACQ-7: Asthma Control Questionnaire; AQLQ: Asthma Quality of Life Questionnaire; ASUI: Asthma Symptom Utility Index; CAE: Clinical asthma exacerbation; Cl: Confidence interval; EOS: Blood eosinophil level; FEF $_{25-75 \%}$ : Forced expiratory flow at $25-75 \%$ of pulmonary volume; $\mathrm{FEV}_{1}$ : Forced expiratory volume in $1 \mathrm{~s}$; FVC: Forced vital capacity; ICS: Inhaled corticosteroid; IL-5: Interleukin-5; IV: Intravenous; LS: Least square; q4w: Every 4 weeks; SE: Standard error. 


\section{Acknowledgements}

This analysis was sponsored by Teva Branded Pharmaceutical Products R\&D, Inc. Medical writing support for the development of this manuscript was provided by Melanie Francis and lan C Grieve, PhD, of Ashfield Healthcare Communications, part of UDG Healthcare plc, and was funded by Teva Branded Pharmaceutical Products R\&D, Inc.

\section{Authors' contributions}

JCV, LH, ED and MG who meet authorship criteria are listed as authors, and all authors certify that they have participated sufficiently in the work to take public responsibility for the content, including participation in the concept, design, analysis, writing, or revision of the manuscript. All authors contributed to the first draft. Subsequent drafts were reviewed. All authors read and approved the final manuscript.

\section{Funding}

Funding was provided by Teva Branded Pharmaceutical Products R\&D, Inc.

\section{Availability of data and materials}

Additional data available on request.

\section{Ethics approval and consent to participate}

Both trials were conducted in accordance with Good Clinical Practice guidelines, the Declaration of Helsinki, and local regulatory requirements. The relevant health authorities and local ethics committees or institutional review boards approved the study protocols. All patients provided written informed consent.

\section{Consent for publication}

Not applicable.

\section{Competing interests}

JCV has lectured for and received honoraria from Allergopharma, ALK, Asche Chiesi, AstraZeneca, Avontec, Bayer, Bencard, Bionorica, Boehringer Ingelheim, Cipla, Essex/Schering-Plough, GSK, Janssen-Cilag, Laboratorios LETI, Meda Pharmaceuticals, Merck/MSD, Mundipharma, Novartis, Nycomed/ ALTANA, Pfizer, Regeneron, Revotar Biopharmaceuticals, Sandoz/Hexal, Sanofi, Stallergenes, Takeda, Teva Pharmaceuticals, UCB/Schwarz Pharma, Zydus Cadila and possibly others and has participated in advisory boards for Asche Chiesi, Avontec, Boehringer Ingelheim, Essex/Schering-Plough, GSK, Janssen-Cilag, MSD, Mundipharma, Novartis, the Paul-Ehrlich-Institut, Revotar Biopharmaceuticals, Sandoz/Hexal, Sanofi, Takeda, TEVA, UCB/Schwarz Pharma and possibly others and has received grants from the Deutsche Forschungsgemeinschaft, Land Mecklenburg-Vorpommern, GSK, MSD. LH is a former employee of Teva Pharmaceuticals. MG and ED are employees of Teva Pharmaceuticals.

\section{Author details}

${ }^{1}$ Departments of Pneumology/Intensive Care Medicine, University Medical Center, University of Rostock, Rostock, Germany. ${ }^{2}$ Former Employee of Teva
Branded Pharmaceutical Products R\&D Inc., West Chester, PA, USA. ${ }^{3}$ Teva Branded Pharmaceutical Products R\&D Inc., West Chester, PA, USA.

Received: 11 November 2019 Accepted: 3 April 2020

Published online: 19 April 2020

\section{References}

1. ten Brinke A, Zwinderman AH, Sterk PJ, Rabe KF, Bel EH. Factors associated with persistent airflow limitation in severe asthma. Am J Respir Crit Care Med. 2001;164:744-8

2. Amelink M, de Groot JC, de Nijs SB, Lutter R, Zwinderman AH, Sterk PJ, et al. Severe adult-onset asthma: a distinct phenotype. J Allergy Clin Immunol. 2013;132:336-41.

3. Virchow JC. Intrinsic Asthma. In: Busse WW, Holgate ST, editors. Asthma and rhinitis, Chapter 89. Oxford: Blackwell Science; 2000. p. 1355-78.

4. Virchow JC, Kroegel C, Walker C, Matthys H. Cellular and immunological markers of allergic and intrinsic bronchial asthma. Lung. 1994;172:313-34.

5. O'Byrne PM, Inman MD, Parameswaran K. The trials and tribulations of IL-5, eosinophils, and allergic asthma. J Allergy Clin Immunol. 2001;108:503-8.

6. Farne HA, Wilson A, Powell C, Bax L, Milan SJ. Anti-IL5 therapies for asthma. Cochrane Database Syst Rev. 2017:9:CD10834.

7. Walsh GM. Profile of reslizumab in eosinophilic disease and its potential in the treatment of poorly controlled eosinophilic asthma. Biologics. 2013;7:7-11.

8. Castro M, Zangrilli J, Wechsler ME, Bateman ED, Brusselle GG, Bardin P, et al. Reslizumab for inadequately controlled asthma with elevated blood eosinophil counts: results from two multicentre, parallel, double-blind, randomised, placebo-controlled, phase 3 trials. Lancet Respir Med. 2015;3:355-66.

9. CINQAIR (reslizumab) injection. Prescribing information, Teva Respiratory LLC. Frazer, PA. 2016. https://www.accessdata.fda.gov/drugsatfda_docs/ label/2016/761033lbl.pdf. Accessed 11 Mar 2020.

10. Hancox RJ, Pavord ID, Sears MR. Associations between blood eosinophils and decline in lung function among adults with and without asthma. Eur Respir J. 2018;51:4.

11. National Asthma Education and Prevention Program. Expert Panel Report 3: Guidelines for the Diagnosis and Management of Asthma. Full Report 2007. https://www.nhlbi.nih.gov/sites/default/files/media/docs/asthg dln_1.pdf. Accessed 11 Mar 2020.

\section{Publisher's Note}

Springer Nature remains neutral with regard to jurisdictional claims in published maps and institutional affiliations.

Ready to submit your research? Choose BMC and benefit from:

- fast, convenient online submission

- thorough peer review by experienced researchers in your field

- rapid publication on acceptance

- support for research data, including large and complex data types

- gold Open Access which fosters wider collaboration and increased citations

- maximum visibility for your research: over 100M website views per year

At $B M C$, research is always in progress.

Learn more biomedcentral.com/submissions 